\title{
Optical Performance and Durability of Solar Reflectors Protected by an Alumina Coating
}

C.E. Kennedy

National Renewable Energy Laboratory

R.V. Smilgys and D.A. Kirkpatrick Science Applications International Corporation

J.S. Ross

Armstrong World Industries

Prepared for presentation at the International Conference on Metallurgical Coatings and Thin Films, April 22-26, 1996, San Diego, California

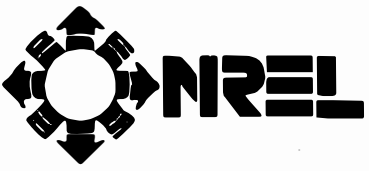

National Renewable Energy Laboratory 1617 Cole Boulevard Golden, Colorado 80401-3393

A national laboratory of the U.S. Department of Energy Managed by Midwest Research Institute for the U.S. Department of Energy under contract No. DE-AC36-83CH10093

Prepared under Task No. SE612033

July 1996 


\section{NOTICE}

This report was prepared as an account of work sponsored by an agency of the United States government. Neither the United States government nor any agency thereof, nor any of their employees, makes any warranty, express or implied, or assumes any legal liability or responsibility for the accuracy, completeness, or usefulness of any information, apparatus, product, or process disclosed, or represents that its use would not infringe privately owned rights. Reference herein to any specific commercial product, process, or service by trade name, trademark, manufacturer, or otherwise does not necessarily constitute or imply its endorsement, recommendation, or favoring by the United States govemment or any agency thereof. The views and opinions of authors expressed herein do not necessarily state or reflect those of the United States government or any agency thereof.

Available to DOE and DOE contractors from:

Office of Scientific and Technical Information (OSTI)

P.O. Box 62

Oak Ridge, TN 37831

Prices available by calling (423) $576-8401$

Available to the public from:

National Technical Information Service (NTIS)

U.S. Department of Commerce

5285 Port Royal Road

Springfield, VA 22161

(703) $487-4650$ 


\title{
OPTICAL PERFORMANCE AND DURABILITY OF SOLAR REFLECTORS PROTECTED BY AN ALUMINA COATING
}

\author{
C. E. Kennedy
}

National Renewable Energy Laboratory, 1617 Cole Blvd, Golden, CO 80401-3393

R.V. Smilgys, D. A. Kirkpatrick

Science Applications International Corporation, 1710 Goodridge Dr., M/S 2-3-1, McLean, VA 22102

\section{J. S. Ross}

Armstrong World Industries, 2500 Columbia Ave., Lancaster, PA, 17604

Solar thermal electric power systems use large solar reflectors to concentrate sunlight to generate electricity. The economic viability of these systems depends on developing a durable, low-cost reflector. The goals for such a reflector are specular reflectance above $90 \%$ for at least 10 years under outdoor service conditions and a large-volume manufacturing cost of less than $\$ 10.8 / \mathrm{m}^{2}$ $\left(\$ 1.00 / \mathrm{ft}^{2}\right)$. Currently, the best candidate materials for solar reflectors are silver-coated, low-iron glass and silvered polymer films. Polymer reflectors are lighter in weight, offer greater system design flexibility, and have the potential for lower cost than glass reflectors. A promising lowcost reflector consists of a silvered polymer protected by an optically transparent alumina coating. The coating is deposited by an ion-beam-assisted physical vapor deposition (IBAD) technique. Samples of this reflector have maintained high optical performance in accelerated testing at the National Renewable Energy Laboratory for more than 3000 hours. Solar reflectors produced using this technique may represent an opportunity to bring solar power generation to reality.

Key Words: alumina, ion-beam-assisted deposition (IBAD), advanced solar reflector 


\section{INTRODUCTION}

The widespread application of solar thermal electric power generation requires development of advanced solar reflector materials that maintain high performance for decades in outdoor service and are capable of being manufactured in large volume at a competitive cost. The National Renewable Energy Laboratory (NREL) is developing these materials for the U.S. Department of Energy Solar Thermal Electric Program. A specific goal is to obtain and demonstrate reflectors that maintain specular reflectance above $90 \%$ (with half acceptance angle of $4 \mathrm{mrad}$ ) for at least 10 years in outdoor service, with a cost to manufacturers less than $\$ 10.8 / \mathrm{m}^{2}$ $\left(\$ 1.00 / \mathrm{ft}^{2}\right)[1]$. The present state of the art in solar reflector materials consists of back-surfacesilvered, low-iron glass and back-surface-silvered polymethylmethacrylate (PMMA) film.

These materials may meet the current reflector goals [2], but it is questionable whether they can meet a longer lifetime goal of 30 years of outdoor service. Silvered PMMA has several limitations, including—relative high cost, a lifetime less than 30 years, and poor adhesion between the silver and PMMA on exposure to water [3]. The limitations of silvered thin (1.0 mm thick) glass are its relative high cost, fragility in shipping and handling, and the availability of only a single U.S. manufacturer.

In an ongoing project sponsored by NREL, Science Applications International Corporation (SAIC) is developing a reflector that may meet NREL's longer lifetime goal. The material is a front-surface reflector that consists of a silvered, copper-backed polymer substrate protected by a transparent inorganic top coating (Fig.1). Earlier, this basic design was recognized as having high potential, but the difficulty has been to find a durable top coating. Polyethylene terephthalate (PET) film was selected as the substrate material because of its low cost, good mechanical properties, and compatibility with silver adhesion. 
The alumina top coating is essential to sustain high reflectance in outdoor service. The coating is deposited by ion-beam-assisted physical vapor deposition (IBAD) [4]. The IBAD technique has been widely used to deposit thin optical coatings [5]. Recently, IBAD was optimized to deposit thick coatings (up to $25 \mu \mathrm{m}$ ) onto plastic substrates [6].

The principal limitation to wider application of IBAD is a relatively low deposition rate attributable to the low output of commercial ion sources capable of operating in an oxidizing atmosphere. A cost analysis of producing a solar reflector using IBAD has been performed to determine the coating deposition rate and thickness consistent with a final reflector cost below $\$ 10.8 / \mathrm{m}^{2}\left(\$ 1.00 / \mathrm{ft}^{2}\right)[7]$. It is projected that with a coating $2 \mu \mathrm{m}$ thick, the deposition rate has to be at least $35 \mathrm{~nm} / \mathrm{s}$, whereas with a coating $4 \mu \mathrm{m}$ thick, the deposition rate has to be at least 60 $\mathrm{nm} / \mathrm{s}$ to attain this cost goal [7]. These rates may be achieved using commercial deposition equipment.

In this paper, we report on the optical performance and durability of silvered PET protected by an alumina top coating. The durability performance of the reflector thus far achieves NREL's criteria for reflectance and specularity under accelerated exposure testing. Such a frontsurface reflector protected by an alumina coating 0.5 to $4 \mu \mathrm{m}$ thick is a promising solar reflector.

\section{EXPERIMENTAL}

\subsection{Sample production}

Samples of solar reflector material were produced in a laboratory chamber equipped for electron-beam evaporation and ion-beam bombardment. The basic components consist of a 66-cm-wide box coater, a CTI Cryogenics CT-10 cryopump, a Temescal STIH-270-2MB four crucible "Supersource" with an 8-kW Temescal CV-8 power supply, a Denton Vacuum model 
DV-SJ/26 cold-cathode ion source, and an Inficon IC6000 deposition controller. The chamber is also equipped with a cryoshield to prevent radiation from heating the substrates when they are not directly over the crucible. The chamber temperature in the vicinity of the substrates is monitored using a thermocouple.

Sheets of PET (76 $\mu \mathrm{m}$ thick, Hoechst-Celanese Hostaphan type 4507 graphic arts film) were mounted on circular holders affixed to a planetary rotation system. In a typical deposition run, 4 samples of reflector material could be produced, each $15 \mathrm{~cm} \mathrm{x} 15 \mathrm{~cm}$ in size.

A typical deposition run would begin by pumping overnight to reach a base pressure of about $1.3 \times 10^{-4} \mathrm{~Pa}\left(10^{-6}\right.$ torr). Once the cryoshield was cold, the substrates would be cleaned by argon ion bombardment for 5 minutes. Then, $50 \mathrm{~nm}$ of copper, followed by $100 \mathrm{~nm}$ of silver, would be deposited using the electron-beam evaporator set at a $1-\mathrm{nm} / \mathrm{s}$ rate. Next, the alumina evaporation rate would be set to $1 \mathrm{~nm} / \mathrm{s}$. During this time, the substrates would be blocked by a shutter. Once the evaporation rate and ion source were stable, the shutter would be opened to begin deposition. To avoid thermal damage to the PET, after completion of the first micron of alumina the electron beam and ion source would be turned off. Only after the chamber had cooled down to at least $10^{\circ} \mathrm{C}$ would deposition begin on the next micron. Further details of the process have been reported [6].

\subsection{Optical performance}

Samples were laminated onto 6061 T6 aluminum substrates with 3M pressure-sensitive adhesive using a laboratory laminator (Chemsultants International) at $276 \mathrm{kPa}$. The sample size used for outdoor and accelerated testing was $4.5 \mathrm{~cm} \times 6.7 \mathrm{~cm}$, and solar simulator samples were $2.5 \mathrm{~cm} \times 2.5 \mathrm{~cm}$ in size. Unlaminated membrane samples $10.2 \mathrm{~cm} \times 10.2 \mathrm{~cm}$ in size were also prepared. 
The hemispherical reflectance of the samples was measured using a Perkin-Elmer Lambda 9 UV-VIS-NIR spectrophotometer with a 60-mm, integrating-sphere attachment. The solar-weighted (air-mass 1.5) hemispherical reflectance was calculated from data collected in the 250-2500-nm range. The absolute specular reflectance was measured as a function of acceptance angle using a special reflectometer developed at NREL [8]. The measurements were made at 4, $8,12,18$, and $25-\mathrm{mrad}$ full-cone angles at $650 \mathrm{~nm}$ on membrane samples stretched to a predetermined tension.

\subsection{Durability testing}

The durability of the solar reflector material was demonstrated by testing under real-time outdoor exposure and by accelerated exposure. Outdoor exposure was performed in Golden, Colorado, one of eight outdoor test sites operated by NREL and equipped with meteorological monitoring capability.

Accelerated testing was performed in an Atlas Weather-Ometer, a Hereaus XENO 1200 LM (XENO), and a 1000-W Oriel Solar Simulator. The Weather-Ometer, XENO, and Solar Simulator allow control of exposure temperature and ambient humidity. They use a xenon-arc light source with filters designed to closely match the terrestrial air-mass 1.5 solar spectrum. The Weather-Ometer operates continuously at $60^{\circ} \mathrm{C}$ and $80 \%$ relative humidity (RH), with light levels about equal to outdoor exposure. A single day of testing ( 24 hours) is roughly equivalent to three times the outdoor exposure in terms of light intensity. The XENO operates continuously at $60^{\circ} \mathrm{C}$ and $80 \% \mathrm{RH}$, with light levels about twice those of the Weather-Ometer. The Solar Simulator operates at $80^{\circ} \mathrm{C}$ and $80 \% \mathrm{RH}$ and can achieve intensities of 30 to 50 times the outdoor exposure in a wavelength band between 300 and $500 \mathrm{~nm}$. 
The spectral intensity distribution of the various light sources in the accelerated exposure chambers was verified using a spectral radiometer system. Trend analysis of the optical performance durability was performed using RS/1 software, a data-analysis system by BBN Software Products Corporation.

\section{RESULTS AND DISCUSSION}

Table I identifies the deposition structure of samples tested. As produced, the samples were free of cracks and showed excellent adhesion to the PET substrate.

\subsection{Optical performance}

The hemispherical reflectance for a typical sample is shown in Figure 2. The solarweighted hemispherical reflectance is about $95 \%$. The initial specular reflectance within an 8mrad full-cone angle is about $91 \%$.

Figures $3 \mathrm{a}$ and $3 \mathrm{~b}$ show the optical durability of samples exposed in the Solar Simulator chamber. All of the samples sustained up to 1800 hours of exposure without degradation of the solar-weighted hemispherical reflectance. For some samples, exposure continued up to 3500 hours with little to no loss of reflectance. No difference could be discerned between samples with an alumina coating between $0.7 \mu \mathrm{m}$ and $5 \mu \mathrm{m}$ thick. This is the longest solar simulator exposure time for a reflector with a polymer substrate tested at NREL to date.

Samples have been under exposure at the outdoor site for 7 months without discernible degradation of hemispherical reflectance. This is true for all alumina-coating thicknesses (Figure 4).

Samples exposed in the Weather-Ometer maintained their initial hemispherical reflectance for all alumina thicknesses, with one exception (Figure 5a). The samples from run \# 04/21/95 
began to delaminate after 3 months. The ion-bombardment level was higher during this run, which may have led to a higher level of residual compressive stress in the alumina coating.

Samples from run \#'s 01/26/95 and 02/09/95 were biaxially stretched to prepare them for reflectometer testing. This stretching caused cracks to form in the alumina coating. The cracked samples were then exposed in the Weather-Ometer. Despite the cracks, the samples have not degraded in terms of hemispherical reflectance (Figure 5b).

Durability testing of candidate samples is also underway in the XENO exposure chamber. Although promising, the samples have been under test for to brief a time to report the results now.

The samples produced by SAIC represent a dramatic improvement in optical durability compared to samples previously tested by NREL. Alternate alumina coatings have been deposited by sputtering, electron-beam evaporation without ion bombardment, and by a variety of ion/plasma-assisted deposition techniques; none of which exhibited promising optical durability and gave significantly poorer results. The samples survived for as little as 1 week and as long as 3 months in accelerated testing and outdoor exposure. The failure of these materials has been correlated to either poor adhesion of the alumina to the silver, excessive stress in the alumina coating that caused cracking, or an alumina coating of insufficient density to protect the silver from atmospheric degradation. These problems have apparently been eliminated by the deposition process discussed in this paper.

\section{CONCLUSION}

Silvered PET with a protective alumina coating deposited by IBAD represents an advancement in solar reflector durability. Samples of the reflector have shown an initial hemispherical reflectance of $95 \%$ and outstanding optical performance in both accelerated and 
outdoor (Colorado) exposure testing. These results are preliminary, and further testing is ongoing. Additional issues to address include determining the minimum coating thickness needed to ensure optical durability, increasing the deposition rate, and the long-term mechanical stability of the material under biaxial strain. The material under development offers promise as a commercially viable solar reflector material.

\section{ACKNOWLEDGMENTS}

C. E. K. acknowledges R. Goggin, G. Jorgensen, D. King, and B. Schelinbarger from NREL. R. V. S. and D. A. K. thank D. M. Althouse for excellent technical work and J. A. Isaacs the cost analysis. J. S. R. acknowledges D. J. Kester, T. P. Medill, and R. A. Hallman at Armstrong World Industries for invaluable assistance in the course of this work. This work was partially supported by the U.S. Department of Energy under Contract No. DE-AC36-83CH10093. 


\section{REFERENCES}

[1] U.S. Department of Energy, National Solar Thermal Technology Program, Five Year Research and Development Plan 1986-1990, DOE/CE-0160, Sept. 1986.

[2] P. Schissel, G. Jorgensen, C. Kennedy, and R. Goggin, Sol. Energy Mater., 33 (1994) 183.

[3] P. Schissel, C. Kennedy, and R. Goggin, J. Adh. Sci. Tech., 9 (1995) 413.

[4] F. A. Smidt, Inter. Mat. Rev. 35 (1990) 61.

[5] U. J. Gibson, Phys. of Thin Films 13 (1987) 109.

[6] J. S. Ross, R. A. Hallman, D. J. Kester, and J. D. Wisnosky, Proc. 38 Ann. Tech. Conf. SVC (1995) 81.

[7] J. A. Isaacs, unpublished report, Materials Systems Laboratory, MIT.

[8] I. Susemihl and P. Schissel, Sol. Energy Mater. 16 (1987) 403. 


\begin{tabular}{|c|l|l|}
\hline \multicolumn{3}{|c|}{ Table I. Deposition Structure of Samples Tested } \\
\hline $\begin{array}{c}\text { Structure } \\
\text { Definition }\end{array}$ & $\begin{array}{l}\text { Run } \\
\text { Number }\end{array}$ & Deposition Structure \\
\hline $\mathrm{A}$ & $12 / 10 / 93-1 \mathrm{~B}$ & Non-optimized $\mathrm{Al}_{2} \mathrm{O}_{3} / \mathrm{Ag} / \mathrm{PET}$ \\
\hline $\mathrm{B}$ & $01 / 26 / 95$ & $\mathrm{Al}_{2} \mathrm{O}_{3}(5.2 \mu \mathrm{m}) / \mathrm{Ag}(70 \mathrm{~nm}) / \mathrm{Cu}(40 \mathrm{~nm}) /$ PET \\
\hline $\mathrm{C}$ & $01 / 26 / 95-1 \mathrm{~B}$ & $\mathrm{Al}_{2} \mathrm{O}_{3}(5.2 \mu \mathrm{m}) / \mathrm{Ag}(70 \mathrm{~nm}) / \mathrm{Cu}(40 \mathrm{~nm}) / \mathrm{Glass}$ \\
\hline $\mathrm{D}$ & $02 / 09 / 95$ & $\mathrm{Al}_{2} \mathrm{O}_{3}(4 \mu \mathrm{m}) / \mathrm{Ag}(70 \mathrm{~nm}) / \mathrm{Cu}(40 \mathrm{~nm}) /$ PET \\
\hline $\mathrm{E}$ & $02 / 09 / 95-1 \mathrm{~B}$ & $\mathrm{Al}_{2} \mathrm{O}_{3}(4 \mu \mathrm{m}) / \mathrm{Ag}(70 \mathrm{~nm}) / \mathrm{Cu}(40 \mathrm{~nm}) / \mathrm{Metal}$ \\
\hline $\mathrm{F}$ & $02 / 28 / 95$ & $\mathrm{Al}_{2} \mathrm{O}_{3}(2 \mu \mathrm{m}) / \mathrm{Ag}(70 \mathrm{~nm}) / \mathrm{Cu}(40 \mathrm{~nm}) / \mathrm{PET}$ \\
\hline $\mathrm{G}$ & $04 / 21 / 95$ & $\mathrm{Al}_{2} \mathrm{O}_{3}(4.5 \mu \mathrm{m}) / \mathrm{Ag}(100 \mathrm{~nm}) / \mathrm{Cu}(50 \mathrm{~nm}) / \mathrm{PET}$ \\
\hline $\mathrm{H}$ & $05 / 02 / 95$ & $\mathrm{Al}_{2} \mathrm{O}_{3}(1.4 \mu \mathrm{m}) / \mathrm{Ag}(100 \mathrm{~nm}) / \mathrm{Cu}(50 \mathrm{~nm}) / \mathrm{PET}$ \\
\hline $\mathrm{I}$ & $05 / 08 / 95$ & $\mathrm{Al}_{2} \mathrm{O}_{3}(0.7 \mu \mathrm{m}) / \mathrm{Ag}(100 \mathrm{~nm}) / \mathrm{Cu}(19 \mathrm{~nm}) / \mathrm{PET}$ \\
\hline
\end{tabular}




\section{FIGURE CAPTIONS:}

Figure 1. Advanced solar reflector material structure. Alumina protective layer, silver reflective layer, copper back-protective layer on PET substrate.

Figure 2. Typical solar-weighted (air-mass 1.5) hemispherical reflectance spectrum for an alumina-protected silver reflector (Run \# 04/21/95). Depending on alumina thickness, fringing can occur.

Figure 3a. Hemispherical reflectance (\%) of alumina reflectors versus time of exposure in solar simulator (in hours).

Figure 3b. Hemispherical reflectance (\%) of alumina reflectors versus time of exposure in solar simulator (in hours).

Figure 4. Hemispherical reflectance (\%) of alumina reflectors versus time of exposure outdoors in Colorado (OD-CO) (in months).

Figure 5a. Hemispherical reflectance (\%) of alumina reflectors versus time of exposure in Weather-Ometer (WOM) (in months). Due to the deposition conditions, Structure G (Run \# 04/21/95) failed by alumina delamination after 3 months in the WOM.

Figure 5b. Hemispherical reflectance (\%) of alumina reflector membranes versus time of exposure in Weather-Ometer (WOM) (in months). 


\section{Top Protective Layer $\left(\mathrm{Al}_{2} \mathrm{O}_{3}\right)$}

\section{Reflective Layer (Ag)}

\section{Metal Back Layer (Cu)}

\section{Substrate (PET)}




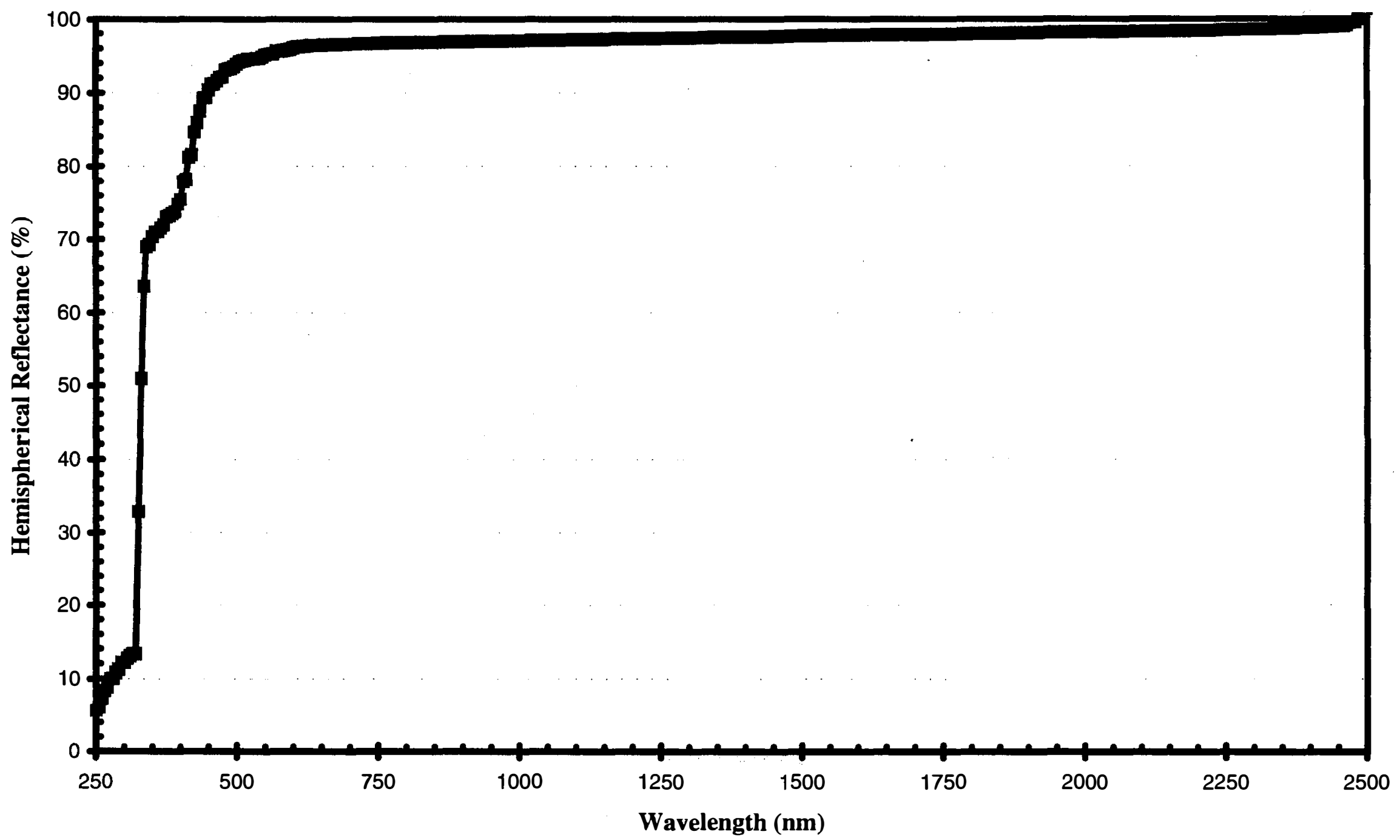




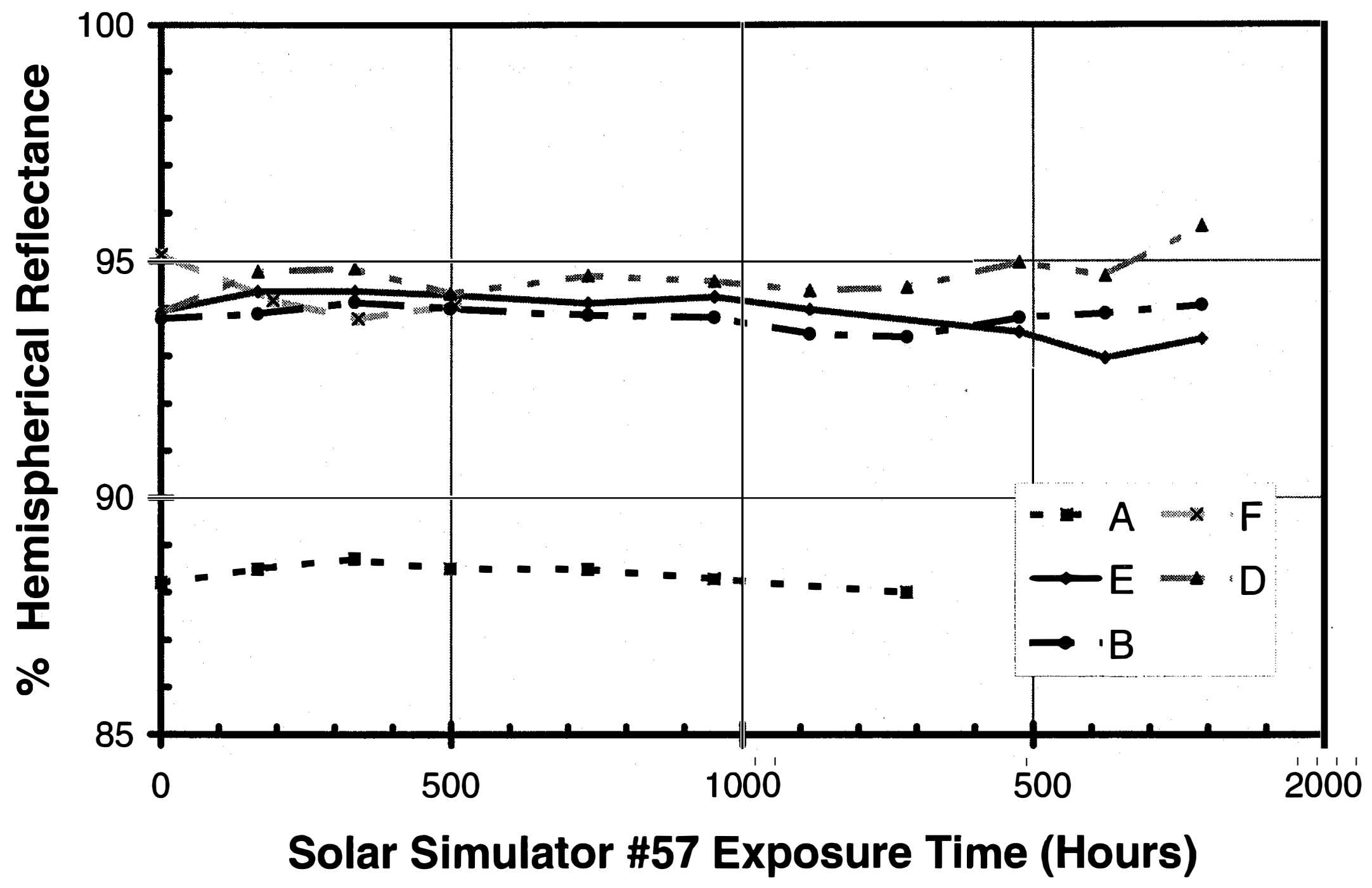




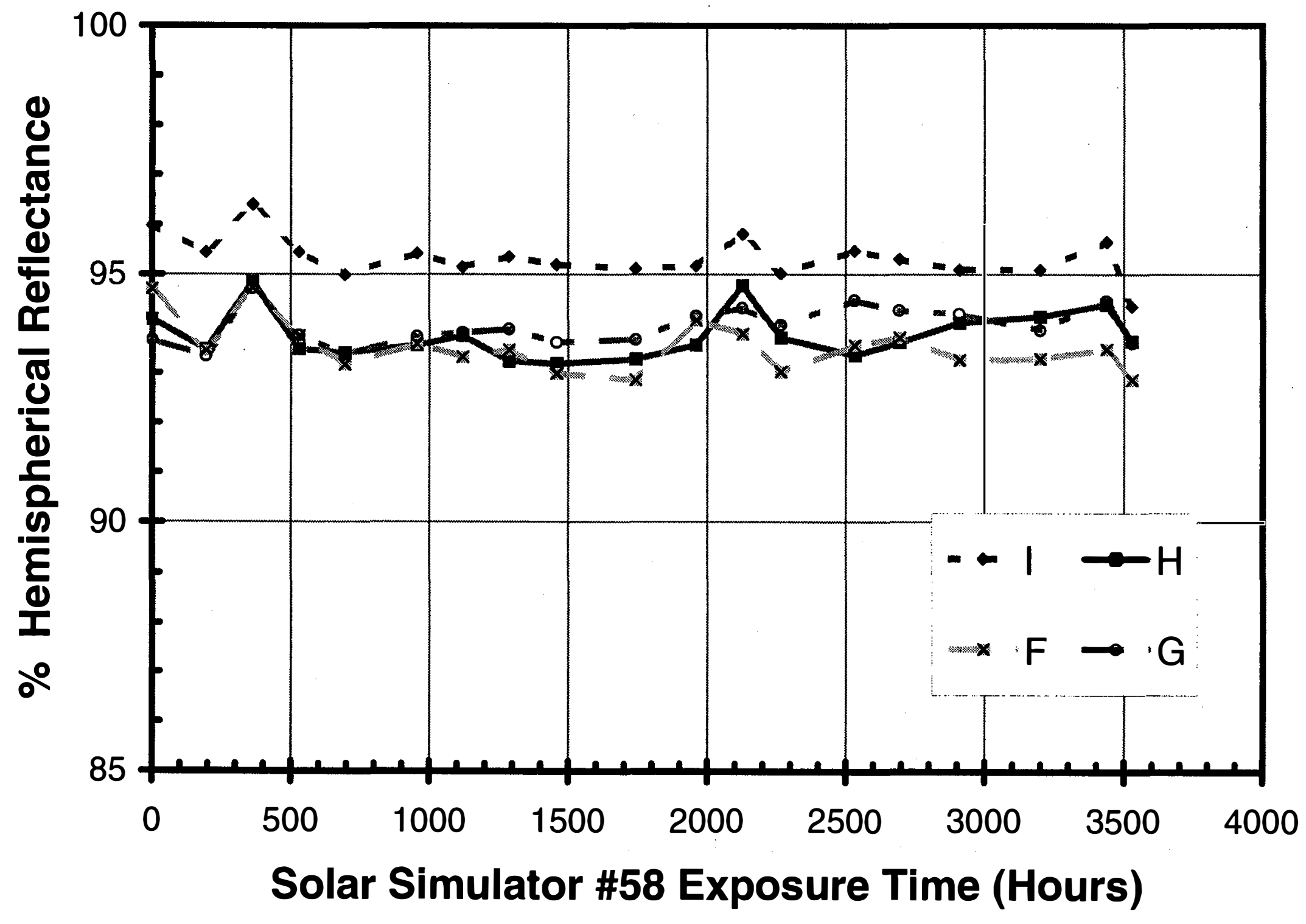




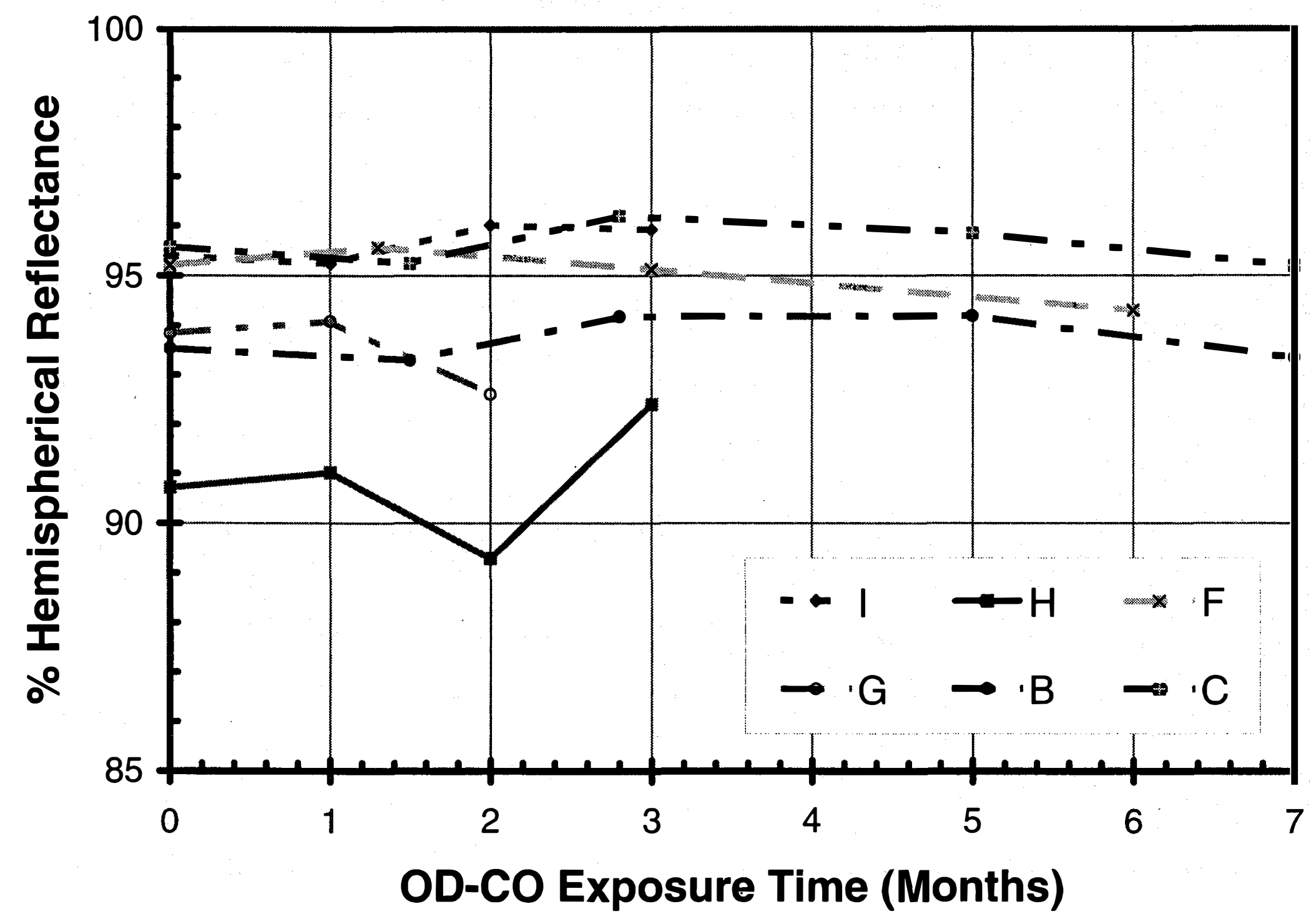




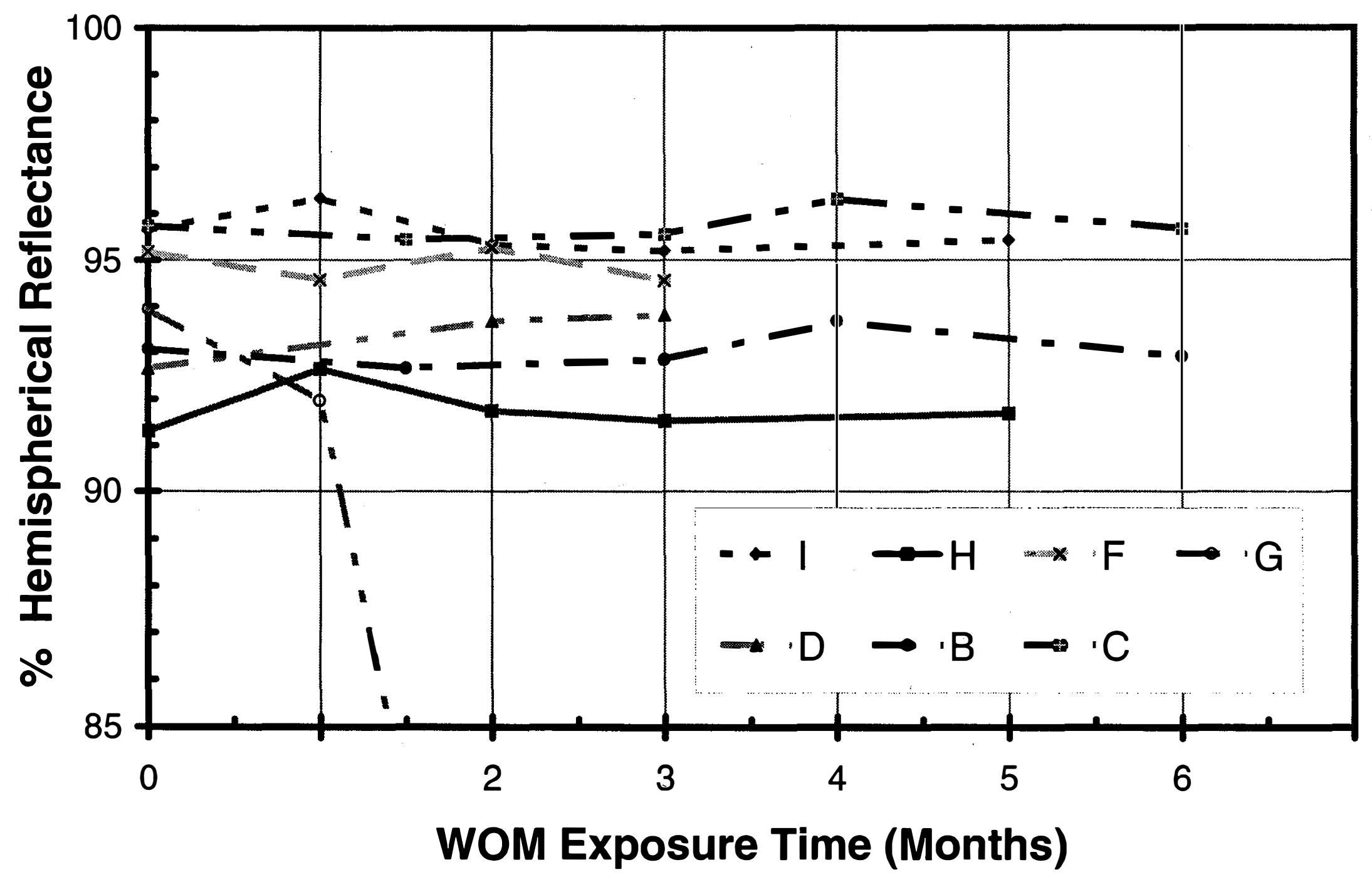




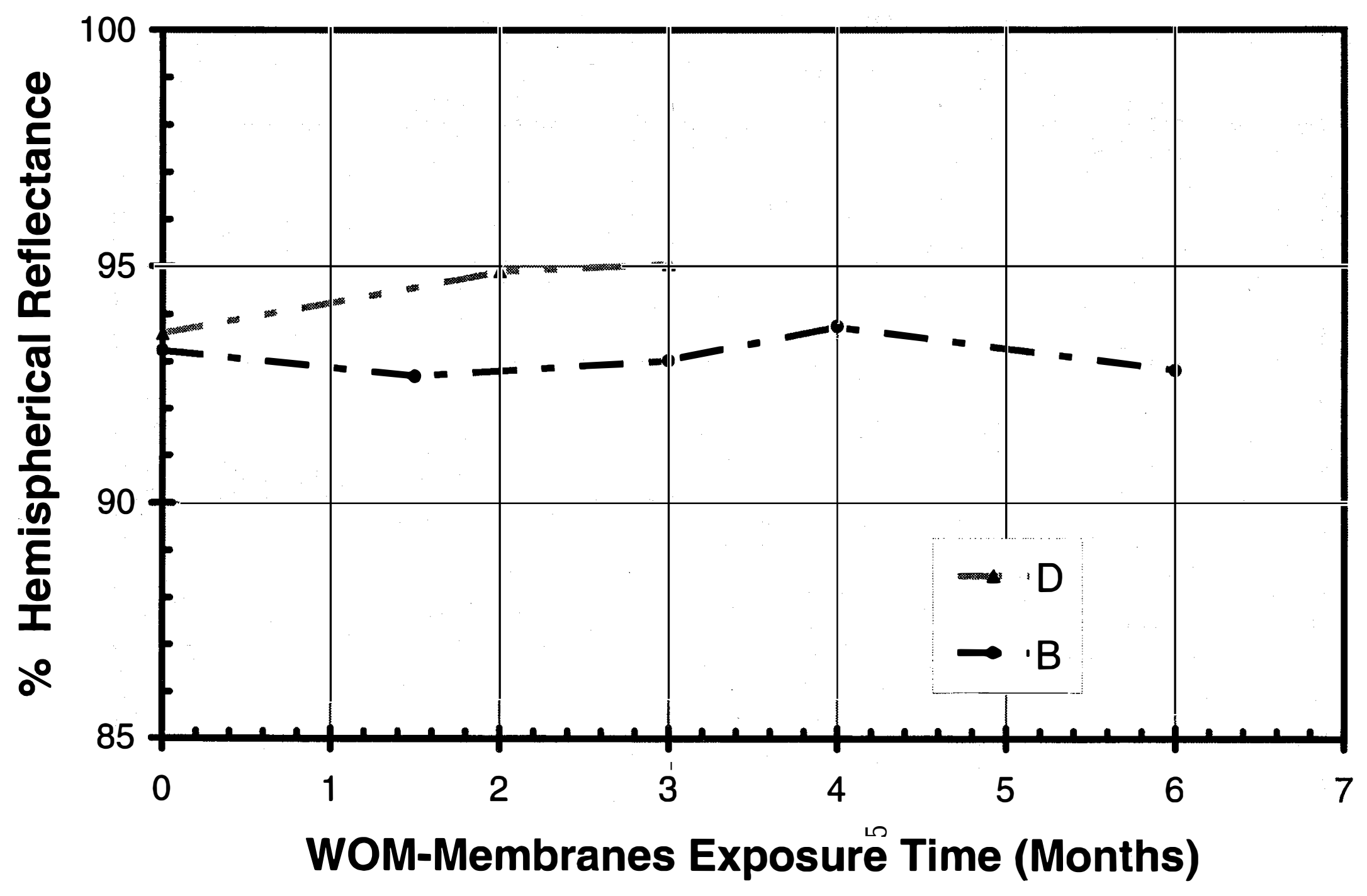

